\title{
PHYSICAL EXERCISE TOWARDS THE CHANGING SCORE OF RISK FALLS ON ELDERLY
}

\section{(Senam Kebugaran Jasmani Lansia terhadap Perubahan Skor Risiko Jatuh Lansia)}

\author{
Silvia Malasari*, Nuurhidayat Jafar*, Ade Irma Rahayu** \\ *Lecturer of Gerontology and Community Nursing, Nursing Study Program, \\ Faculty of Medicine, Hasanuddin University \\ $* *$ Students of Nursing Study Program, Faculty of Medicine, Hasanuddin University \\ E-mail: ners.silvi@gmail.com
}

\begin{abstract}
ABSTRAK
Pendahuluan. Kejadian jatuh pada lanjut usia yang berusia 65 tahun ke atas di Indonesia adalah sekitar 30-50\% setiap tahunnya. Latihan fisik diharapkan dapat mengurangi risiko jatuh pada lansia. Penelitian ini bertujuan untuk mengidentifikasi pengaruh senam kebugaran jasmani (SKJ) lansia terhadap perubahan skor risiko jatuh di Kelurahan Tammua, Kecamatan Tallo, Kota Makassar. Metode. Penelitian ini menggunakan quasi-experimental design dengan rancangan one group pretest-posttest design. Sampel diambil menggunakan purposive sampling, di mana diperoleh sampel sebanyak 17 lansia. Data diuji menggunakan Paired Sample T-Test. Hasil. Didapatkan pengaruh bermakna SKJ lansia terhadap perubahan skor risiko jatuh lansia $(p=0,000)$. Diskusi. Ada pengaruh SKJ lansia terhadap perubahan skor risiko jatuh yang dilihat dari penurunan skor risiko jatuh lansia, diharapkan kepada para kader untuk tetap rutin melaksanakan SKJ ini minimal sekali seminggu di sebagai upaya pencegahan jatuh sejak dini.
\end{abstract}

Kata kunci: Senam lansia, risiko jatuh, lansia

\section{ABSTRACT}

Introduction. Incidence of falls in elderly whose above 65 years old in Indonesia is approximately 30-50\% annually. Physical exercise might reduce the risk of fall in elderly. The purpose of this study was to determine the influence of regular physical exercise or "Senam Kebugaran Jasmani" (SKJ) towards fall risk score of elderly in Tammua, Tallo District, Makassar. Method. This study was quasi-experimental design with one group pretest-posttest design. 17 elderly people were collected by purposive sampling technically. Data processing used Paired Sample T-Test. Results. There was significant influence of regular physical exercise towards elderly fall risk score alteration ( $p=0,000$; eta square = 0,64). Discussion. This study revealed that there was an effect of physical exercises towards fall risk score change. This research suggests health volunteer workers (kader) of Tammua to accomodate a regular physical exercise once a week as an early prevention of falls.

Keywords: Regular physical exercise, fall risk, elderly

\section{INTRODUCTION}

Falling is a major cause of most accidents in elderly aged 65 years and over (Forsyth, Quon \& Konkle, 2011). Aging causes a decrease in lower extremity muscle strength. This can lead to slowness of movement, short steps, the feet cannot tread stronger and more volatile (Darmojo, 2011), resulting in falls in elderly.

Physical exercise is a component of interventions designed to identify the risk and fall prevention (American Geriatric Society quoted in Forsyth, Quon \& Konkle, 2011). According to Suhardo (cited in Widyantoro, Rosdiana \& Fasitasari, 2012), gymnastics/ physical exercise (SKJ) is one form of physical exercise that can increase muscle strength and endurance in elderly.

Tammua village, is one of the villages that activate the SKJ for elderly in their working area. But there are still some Rukun Warga (RW) does not organize it routinely. Based on the report of the activities of Geriatric Nursing Practice from Nursing School of Hasanuddin University (PSIK UNHAS) in 2012, it is known that the number of elderly in the village Tamua were 116 people and those with a history of falling were 18 people. Through this research proposal the authors intend to examine the effect of SKJ on the prevention of fall in elderly in Tammua Village, Tallo District, Makassar. 


\section{METHOD}

This research was a quantitative study of Quasi-experimental design with the design of one group pretest-posttest design. The study was conducted in RW 3 and RW 4 Tammua Village, District Tallo, Makassar from the date of July 14, 2014 until August 10, 2014 every Wednesday and Sunday. The sample collection used purposive sampling technique. Sampling was based on the results of screening using the multifactorial falls risk assessment Screening Assessment for Falls Evaluation
(SAFE), which has been modified, in which the elderly fall into the high-risk criteria are with a score $>11$. Collecting data using functional fall risk assessment, the Timed Up and Go test (TUG), which marked a high fall risk elderly when completing this test $\geq 14$ seconds. Leg muscle strength was measured using a leg dynamometer brand Takei A5402. Bivariate analyze by using Paired-Samples T Test using the data in the form of numerical significance value of $p<0.005$ and eta square to see the strength of the effect of SKJ elderly.

\section{RESULT}

Table 1. Frequency Distribution of Fall Risk based on Characteristics of Respondents in RW 3 and RW 4 Tammua, Tallo, Makassar, July-August, $2014(n=17)$

\begin{tabular}{|c|c|c|c|c|}
\hline \multirow{3}{*}{ Characteristics } & \multicolumn{4}{|c|}{ Risk of Fall } \\
\hline & \multicolumn{2}{|c|}{ Low } & \multicolumn{2}{|c|}{ High } \\
\hline & $\mathbf{F}$ & $\%$ & $\mathbf{f}$ & $\%$ \\
\hline \multicolumn{5}{|l|}{ Age } \\
\hline 60-74years (elderly) & 7 & 53.8 & 6 & 46.2 \\
\hline 75-90years (old) & 1 & 25.0 & 3 & 75.0 \\
\hline Total & 8 & 47.1 & 9 & 52.9 \\
\hline \multicolumn{5}{|l|}{ Gender } \\
\hline Male & 1 & 50.0 & 1 & 50.0 \\
\hline Female & 7 & 46.7 & 8 & 53.3 \\
\hline Total & 8 & 47.1 & 9 & 52.9 \\
\hline \multicolumn{5}{|l|}{ History of Fall (12 months) } \\
\hline Never & 8 & 61.5 & 5 & 38.5 \\
\hline Once & - & 0 & 3 & 100 \\
\hline More than once & - & 0 & 1 & 100 \\
\hline Total & 8 & 47.1 & 9 & 52.9 \\
\hline
\end{tabular}

Table 2. Leg Muscle Strength pretest and posttest of Respondents in RW 3 and RW 4 Ex. Tammua, district. Tallo, Makassar, July-August, $2014(\mathrm{n}=17)$

\begin{tabular}{lccccc}
\hline Leg Muscle Strength & Mean & SD & $\begin{array}{c}\text { Std. Error of } \\
\text { Mean }\end{array}$ & Minimum & Maximum \\
\hline Pretest & 24.824 & 7.7801 & 1.886 & 12.5 & 41.0 \\
Posttest & 28.424 & 8.9407 & 2.168 & 12.5 & 46.5 \\
\hline
\end{tabular}

Table 3. The distribution of fall Risk at pretest and posttest among elderly ts in RW 3 and RW 4 Ex. Tammua, district. Tallo, Makassar, July-August, 2014 ( $\mathrm{n}=17)$

\begin{tabular}{lcccc}
\hline \multirow{1}{*}{ Fall risk } & \multicolumn{2}{c}{ Prestest } & \multicolumn{2}{c}{ Posttest } \\
\cline { 2 - 5 } & f & $\mathbf{\%}$ & f & \% \\
\hline Low $(<14$ second $)$ & 8 & 47.1 & 14 & 82.4 \\
High $(\geq 14$ second $)$ & 9 & 52.8 & 3 & 17.6 \\
\hline Total $(\mathrm{n})$ & 17 & 100.0 & 17 & 100.0 \\
\hline
\end{tabular}


Table 4. Paired-Sample T Test (Pre-Post) of risk falls among respondents before and after SKJ Elderly in RW 3 and RW 4, Tammua, district. Tallo, Makassar, in July - August $2014(\mathrm{n}=17)$

\begin{tabular}{lcccccc}
\hline \multirow{2}{*}{$\begin{array}{l}\text { Pretest-Posttest } \\
\end{array}$} & n & SD & \multicolumn{2}{c}{$\begin{array}{c}\text { 95\% Confidence Interval } \\
\text { of the Difference }\end{array}$} & Sig. p value Eta Square \\
\cline { 4 - 6 } & & & Lower & Upper & & \\
\hline Pair PrePost & 17 & 1.541 & 1.208 & 2.792 & 0.000 & 0,64 \\
\hline
\end{tabular}

Table 1 showed that the majority of respondents (8 respondents) who did not have a history of falling can complete the TUG test with fine score $(<14$ seconds).

Significance value for the $\mathrm{p}$ value of the statistical test is 0.000 , smaller than alpha value of 0.05 , indicating a significant influence. The table above showed that half numbers of the respondents have high fall risk before starting SKJ elderly (52.8\%). After the SKJ elderly, the number of respondents with a low risk of falling increased to largely (82.4\%).

\section{DISCUSSION}

The risk of falling among respondents by age was less than half of respondents (52.9\%), have a high risk of falling. This indicates that, with age, the elderly have risk of falls (mean age was 70.41 years). These results are consistent with the theory expressed by Darmojo (2011) who says that fall is one of the main problems for elderly, caused by changes in the physiology of intrinsic factor elderly musculoskeletal system began to decrease.

Three-quarters of female respondents (76.5\%) had high-risk fall before doing SKJ for elderly. As Elanor (cited in Fatmah, 2009) claimed that the generally elderly men are less at risk of falling than women. Women also have less muscle mass than men. Males had a peak bone mass (peak bone mass) is larger and not accelerating bone loss as experienced by women due to loss of estrogen after menopause. Iinattiniemi, Jokelainen \& Luukinen (2008) also state that female can increase the risk of falls in the elderly.

Overall, there are four respondents with a history of falling (once and more than once to fall) who completed the test Timed Up and Go (TUG) $\geq 14$ seconds indicating that the four respondents had high risk of falling. The majority of respondents (8 respondents) who did not have a history of falling can complete the TUG test with fine score $(<14$ seconds). These results are consistent with Farabi's study (2007) which examined the relationship of the TUG test and the frequency of falls. It is stated that the respondents who having slow motion or walking impairment, the incidence of falls increases as TUG test time takes longer. This occurs due to the aging process that occurs in elderly result in changing of postural control that may play a significant role for most falls.

All respondents were in the category of less muscle strength $(<65 \mathrm{~kg})$. Along with the increase of age, the function of musculoskeletal system of elderly was deacrease. One of them is a lack of muscle strength caused by a decrease in muscle mass (muscle atrophy). Decrease in muscle size and loss of muscle mass in elderly is more common in the lower extremities. Bone, joint, and muscle is associated components. If a joint is not used as well as a decrease in bone mass, then the bones and muscles that cross the joints will be shortened, resulting in muscle also weakened. Decrease fall risk score is closely associated with increase of muscle strength. This makes the elderly more powerful in supporting the body.

All respondents were in the category of less leg muscle strength $(<65 \mathrm{~kg})$, however it also illustrates that almost all respondents had an increase in muscle strength scores from pretest to posttest. The lowest score of leg muscles strength, which is $12.5 \mathrm{~kg}$ before SKJ elderly and remains $12.5 \mathrm{~kg}$ after SKJ elderly. This is because the respondents have a fever and the lack of appetite that could have an impact on the decline in the energy metabolism of the respondents. These results are similar to Akmal (2013) which says that 
energy is a major intake required by the body for metabolic processes at the cellular level to maintain balance and to working muscles.

Half numbers of the respondents have high fall risk before starting SKJ elderly $(52.8 \%)$. After the SKJ elderly, the number of respondents with a low risk of falling increases to largely (82.4\%). The opposite occurs in the number of respondents to the high risk of falls decreased from half of the respondents (52.8\%) to $17.6 \%$. This means there is significant changes in the number of respondents in the category of risk of falling. The significant reduction in the mean value of the risk of falls in elderly SKJ respondents after purchase, ie from 13.24 seconds before giving SKJ elderly to 10.75 seconds after administration of SKJ elderly.

Significance value for the $\mathrm{p}$ value of the statistical test is 0.000 , smaller than alpha value of 0.05 , indicating a significant influence. Eta square value of 0.64 is obtained, is greater than 0.14 indicate a strong effect. This means Physical Exercise/SKJ elderly have a strong influence and effects of changes in the elderly of fall risk score. Fall risk score of respondents before and after SKJ elderly decreased significantly. This is shown in table 4.4 which states fall risk ratio pretest and posttest respondents, where there is an increase in the number of respondents with a lower risk of falls, from 8 respondents (47.1\%) before the administration of SKJ to 14 respondents (82.4\%) after SKJ.

Decreased risk of falls each respondent is also displayed numerically which shows the mean values of 13.24 seconds before the treatment becomes 10.76 seconds after treatment. Changes in the mean values indicate significant changes regarding the effect of SKJ elderly towards the changing score of fall risk.

According to Kam, Smulders \& Weerdesteyn (2008), exercise can reduce the incidence of falls, fractures due to falls and fall risk factors in individuals with less bone density. As also expressed by Iinattiniemi, Jokelainen \& Luukinen (2008) in their study of the elderly 85 years and over, who state that the exercise proved to be safe and benefit to reduce the risk of falls due to fracture.

The results of this study indicate that SKJ for elderly have an influence on the decrease of falls risks which increases muscle strength. This is supported by the continuity and duration of SKJ. Muscle strength is very supportive for elderly to support the body so that can reduce the fall risk scores which is seen from the decline in the elderly TUG test score in RW 3 and RW 4, Village Tammua, District Tallo, Makassar.

\section{CONCLUSION}

Physical exercise (SKJ) could affect the score of fall risk of elderly in Tammua village, District Tallo, Makassar.

\section{RECOMMENDATION}

Health Program for elderly should be prioritized in anticipation of the incidents of falls. This includes such actions of preventive health education, gymnastics, and Therapeutic Activity Group (TAK). In addition rehabilitative measures should be developed to prevent the permanent effects of falls in elderly. Elderly Physical fitness (SKJ) is highly recommended to be conducted regularly. The involvement of a kader is expected to facilitate the implementation of this SKJ at least once a week.

\section{REFERENCES}

Akmal, H.F. (2012). Perbedaan asupan energi, protein, aktivitas fisik, dan status gizi antara lansia lansia yang mengikuti dan tidak mengikuti senam bugar lansia. Fakultas Kedokteran Universitas Diponegoro: Semarang, diakses tanggal 25 Januari 2014, http://eprints. undip.ac.id/37552/1/Hilda_Fauzia_AG2A008093-LAP.KTI.pdf

Darmojo, B. (2011). Buku ajar geriatri; ilmu kesehatan usia lanjut edisi ke-4, cetakan ke-3. Fakultas Kedokteran Universitas Indonesia: Jakarta. 
Farabi, A. (2007). Hubungan tes "timed up and go" dengan frekuensi jatuh pasien lanjut usia. Fakultas Kedokteran Universitas Diponegoro: Semarang.

Fatmah. (2009). Osteoporosis dan Faktor Risikonya pada Lansia Etnis Jawa. Media Medika Indonesia: Semarang, diakses tanggal 13 Januari 2014, dari $<$ http://eprints.undip.ac.id/14215/2/01 fatmah___osteoporosis.pdf

Forsyth, A.L., Quon, D.V., Konkle, B.A. (2011). Role of exercise and physical activity on haemophilic arthropathy, fall prevention and osteoporosis. Haemophilia: Philadephia, diakses tanggal 24 Juli 2013, <www.ncbi.nlm. nih.gov/pubmed/21435116 >

Kam, D., Smulders, E., Weerdesteyn, V. (2009). Exercise Interventions to Reduce Fall- related Fractures and Their Risk Factors in Individuals with Low Bone Density; A Systematic Review of Randomized Controlled Trials. Osteoporos Int: Belgium, diakses tanggal 24 Juli 2013.

Linattiniemi, S., dkk. (2008). "Exercise and Risk of Injurious Fall Home-dwelling Elderly", International Journal of Circumpolar Health, diakses tanggal 24 Juli 2013, <www.ncbi.nlm.nih.gov/ pubmed/18767343|>

Widyantoro, A.P., Rosdiana, I., Fasitasari, M. (2012). Hubungan antara senam lansia dan range of motion (ROM) lutut pada lansia, diakses tanggal 21 Agustus 2013, http://sainsmedika.fkunissula. ac.id/index.php/sainsmedika/article/ downlod 